\title{
Access to reproductive health services under the European convention on human rights
}

\begin{abstract}
From a human rights perspective, access to reproductive health care has been accepted as a subset of the human right to health care. Realising reproductive health rights means - among others - access to assisted reproductive technologies (ARTs). This article will examine the individual's claim for access to ARTs under the European Convention on Human Rights, as interpreted by the European Court of Human Rights. It concludes that, although the Convention incorporates a positive State obligation to facilitate reproductive rights, the Court generally respects the wide margin of appreciation of individual States to ban certain types of ARTs. By exception, the Court has accepted a legal claim for access to ART and preimplantation genetic diagnosis, but only due to inconsistencies of national legislation.
\end{abstract}

Keywords: ARTs, positive State obligations,margin of appreciation
Special Issue - 2018

\author{
Andreden Exter \\ Jean Monnet Chair EU Health law, Erasmus University \\ Rotterdam, The Netherlands
}

\begin{abstract}
Correspondence: Andreden Exter, Jean Monnet Chair EU Health law, Institute of Health Policy and Management, Erasmus University Rotterdam, Rotterdam, The Netherlands, Tel +3। 10 408I867, Email denexter@eshpm.eur.nl
\end{abstract}

Received: November 13, 2017 | Published: November 30, 2018

\section{Introduction}

For centuries, mankind has been confronted with (the consequences of) infertility, searching for alternative means starting a family. A wellknown example overcoming infertility has been described in the Old Testament when Sarah, already in her nineties, encouraged Abraham to 'visit' her maid Hagar, who became pregnant giving birth to Ismail. ${ }^{1}$ Such a ménage a trios or surrogacy option has been observed in many cultures. ${ }^{2}$ Nowadays, contemporary medicine and medical technology has developed more sophisticated methods overcoming infertility. The first 'test tube' baby born by in vitro fertilisation (IVF) in the 1970s was generally considered a breakthrough in reproductive health: overcoming female infertility by means of medical or assisted reproductive technologies (ARTs). Since then new methods at the interface of assisted reproduction and genetics have been developed, which enable the selection of genetically 'healthy' embryos and modification of the genetic makeup, causing controversies on genetic selection and 'designer babies'. Each country is dealing with ARTs in its own manner, highly influenced by social, ethical, legal and religious norms and values. Claiming access to reproductive health care services, one of the questions raised, concerns the role of the European Convention on Human Rights, and the European Human Rights Court interpreting the Convention's rights. Hereafter, several high profile Court rulings will be discussed, explaining the limited impact of the Convention.

\section{Understanding reproductive health care rights}

Contemporary medical science offers various treatment options

'Old Testament, Book of Genesis 16(2): "The Lord has kept me (Sarah) from having children. Go, sleep with my slave; perhaps I can build a family through her".

${ }^{2}$ E.g., in ancient Hindu society there existed a practice known as NiyogPratha, wherein the wife was childless due to impotency of her husband. Here the brother in law was the surrogate father, quoted by A.M. Vyas, Surrogacy: The only hope for a few (2017) $3 \operatorname{IJMSSR}$ (2017) p. 44 overcoming male and female infertility, ranging from IVF and related treatment methods, such as preimplantation genetic diagnosis (PGD) and screening (PGS), Intracytoplasmic sperm injection (ICSI) to tackle male infertility, gamete donation, frozen embryo transfer, frozen oocyte replacement (cryopreservation) in case of cancer patients or delaying motherhood, as well as posthumous reproduction and surrogacy arrangements with or without a genetic link between the gestating woman and the child. Future developments include genome editing technologies (CRISPR) for infertility treatment and the idea of 'artificial wombs'. ${ }^{3}$ Understanding the legal context of reproductive care, the analysis focuses on human rights law and access to reproductive health services.

\section{Access to assisted reproductive technologies (ARTs) rights: A human rights perspective}

From a human rights perspective, access to reproductive health care has been accepted as a subset of the human right to health care. Article 12 of the Convention on Economic, Social and Cultural Rights (ICESCR) interprets (sexual and) reproductive health as 'a set of freedoms and entitlements, including the freedom to make free and responsible decisions and choices... over matters concerning... reproductive health and unhindered access to a range of health facilities, goods, services and information' ${ }^{4}$ Since then, such a right

${ }^{3}$ E.g., J.C. Harper (ed) Preimplantation Genetic Diagnosis (2nd ed. CUP 2012); L. Tang and others, CRISPR/Cas9-mediated gene editing in human zygotes using Cas9 protein, Molecular Genetics and Genomics (2017) DOI: 10.1007/ s00438-017-1299-z; A. Deglincertiand others, Self-organization of the in vitro attached human embryo, Nature 533, 251-254 (12 May 2016).

${ }^{4}$ See The Committee on Economic, Social and Cultural Rights (CESCR), General Comment (GC) no. 22 (2016) on the Right to sexual and reproductive health (Art. 12 of the International Covenant on Economic, Social and Cultural Rights), para 5, with references to GC no. 14 (2000): The Right to the highest attainable standard of health (Art. 12). As confirmed by other international human rights documents: Convention on the Elimination of All Forms of Discrimination against Women (1979), Art. 12; Convention on the Rights of the Child (1989), Art. 24(2)(d); and Convention on the Rights of Persons with Disabilities (2006), Arts. 23 and 25. 
has constantly evolved creating specific State obligations in terms of availability, accessibility, acceptability and quality of reproductive health services, as explained in the Convention's General Comment (GC) on the right to sexual and reproductive health (GC no. 22) 5. ${ }^{5}$ This means that States will take all necessary steps (legal and budgetary) to the maximum of available resources, to progressively realise the Convention's right to reproductive health. ${ }^{6}$ Such reproductive health care services 'should be accessible to all individuals and groups without discrimination and free from barriers', whereas accessibility includes 'physical accessibility, affordability and information accessibility'. ${ }^{7}$ In case of ARTs, this means that States are under the immediate obligation to eliminate discrimination against individuals and groups, therefore, lifting the ban on ARTs to same sex couples, single women, and disabled persons. The GC also urges States 'to repeal or reform laws and policies that nullify or impair certain individual's and group's ability to realize their reproductive health right' ${ }^{8}$ Compliance with the Covenant further means that States abstain from 'retrogressive measures'. Examples of retrogressive measures in the context of reproductive rights are revoking public health funding and/or creating barriers to ARTs. ${ }^{9}$

Access to reproductive care can also be based on Article 3 of the Convention on Human Rights and Biomedicine (Oviedo Convention), imposing States an obligation to reach equal access to health care including reproductive services - based on individual health needs and taking into account the available resources. ${ }^{10}$ Here, individual health needs should be interpreted as objective medical needs as concluded by medical professionals. Instead of patient's individual needs, which can be unlimited. ${ }^{11}$ Besides an integral part of the right to health care, reproductive rights are also intrinsically linked with other human rights, such as the right to life, right to private or family life, the prohibition of degrading treatment. Traditionally, classical civil rights protect the individual against arbitrary interference by public authorities (i.e. abstaining from such interference). In addition, such rights may also be interpreted as incorporating inherent positive measures (positive State obligations) such as facilitating reproductive rights, designed to secure civil rights. Notably the European Court of Human Rights (ECtHR) interprets ART cases under the Convention's right to private and family life (Article 8 ECHR), whether or not

${ }^{5}$ The so-called AAAQ-approach: GC no. 22 (2016) on the Right to sexual and reproductive health, paras 11-21, based on GC no. 14; CEDAW General Recommendation (GR) no. 24: Article 12 of the Convention (Women and Health) A/54/38/Rev.1

${ }^{6}$ Idem, para 33.

${ }^{7}$ Idem, para 15 .

${ }^{8}$ Idem para 34.

${ }^{9}$ Idem para 38. Retrogressive measures are in principle prohibited. In more detail, see A. den Exter. The Right to Health Care, in A. den Exter (ed) European Health Law, Maklu Press 2017, p. 113-114.

${ }^{10}$ Officially, the Convention for the Protection of Human Rights and Dignity of the Human Being with regard to the application of Biology and Medicine: Convention on Human Rights and Biomedicine (also known as Oviedo Convention), ETS no. 164.

${ }^{11}$ Article 3 Biomedicine Convention and the Explanatory Report paras 2425, as discussed by M. Buijsen and A. den Exter, 'Equality and The Right to Health Care' in A. den Exter (ed), Human Rights and Biomedicine (Maklu 2010) 69-85. The medical needs concept is also applied by the EU Court of Justice in the prior authorization setting, interpreted as "an objective medical assessment of the clinical needs of the person concerned in the light of all of the factors characterising his medical condition", such as "the history and probable course of his disease, the degree of pain he is in and/or the nature of his disability" (Watts C-372/04 paras 79 and 123). in combination with the non-discrimination principle (Article 14). As such, the Court clarified the nature and scope of positive obligations for particular groups. For instance, in Evans $v U K$, the Court concluded that is not disputed that the decisions to become or not to become a parent by means of IVF treatment, falls within the scope of Article 8 (private and family life). ${ }^{12}$ Unfortunately for Natalie Evans, the Court's balancing of interests (i.e. competing positive obligations) ended unsuccessfully, as she was not allowed to use the embryo. The condition of mutual consent for the implantation of the embryo in the uterus, was not considered as a violation of her private life. ${ }^{13}$ In another case, S.H. and Others $v$ Austria, the Court accepted the prohibition of the use of donated gametes (ova and sperm) from donors for IVF purposes, as a lawful restriction of the applicants' private life. ${ }^{14}$ Different from Evans, here the Court examined the case as an 'interference with the applicants' right to respect their private and family lives, instead of a failure of the State to fulfil a positive obligation in that respect', which was found compatible with Article 8 of the Convention (para 113). More successful was the Costa Pavan case, challenging the Italian ban on ART and preimplantation genetic diagnosis (PGD) to avoid transmitting the genetic disorder - cystic fibrosis - to their offspring. ${ }^{15}$ Since the technique was only available to other categories of patients (infertile couples, HIV persons) which they did not belong, they had no access to ART treatment, in addition to the blanket ban on PGD. Alternatively, the couple was allowed to abort the defective foetus, when it turned out to be affected by the disease (para 62). Such an inconsistency on Italian law on PGD was considered a disproportionate, thus unlawful interference of the couple's private life (paras 64-71).

The latest ART case, Parrillo $v$ Italy, diverges from the above cases since the ban concerned donated gametes through IVF for scientific research purposes..$^{16}$ After the unexpected death of her husband, Ms Parillo decided not to have the embryos implanted but requested unsuccessfully - to release the cryopreserved embryos so that they could be used for stem cell research. The key issue was whether the Law prohibiting research on human embryos was incompatible with Parillo's right to private life. According to the Court's standing case law, private life within the meaning of Article 8 of the Convention embraces, among others, the right to self-determination, meaning the freedom of choice to start a family or not. ${ }^{17}$ In Parillo, the Court elaborates on that right, concluding that the right to self-determination also covers "the ability to exercise a $[\ldots]$ choice regarding the fate of her embryos not destined for implantation (para 159). This is based on the fact that" embryos contain the genetic material of the person in question' and accordingly represent a constituent part of that person's genetic material and biological identity" (para 158). But given the controversy and the lack of consensus among Council of Europe member states on the donation of embryos not intended for implantation, domestic authorities enjoy a broad margin of discretion to enact restrictive legislation banning the donation of human embryos for scientific research. Taking into account the drafting process of the legislative ban, considering the different perspectives, the Court affirmed that Italy has not overstepped the wide margin of

\footnotetext{
${ }^{12}$ Evans v UK, Appl. no. 6339/05 (ECtHR, 10 April 2007) para 71.

${ }^{13}$ Idem paras 75-76 and 92 .

${ }^{14}$ S.H. and Others v Austria Appl. no. 57813/00 (ECtHR 3 November 2011) GC para 89-116.

${ }^{15}$ Costa and Pavan v Italy, Appl. no. 54270/10 (ECtHR 11 February 2013).

${ }^{16}$ Parrillo v Italy, Appl. no. 46470/11 (ECtHR, 27 August 2015 [GC]).

${ }^{17}$ Pretty v UK, Appl. No. 4326/02 (ECtHR,29 April 2002) para 61.
} 
appreciation and that the ban was "necessary in a democratic society" under Article 8(2) of the Convention (para 197). Other examples attempt to bring cross-border surrogate motherhood arrangements and reproductive techniques under Article 8 of the Convention (refusal to register a foreign birth certificate).$^{18}$ As the focus is more on the parent-child relationship, raising fundamental questions of family law (i.e. maternity, paternity custody and children's rights, as well as the mater semper certaest-principle), the transnational surrogacy cases are excluded from this analysis.

Outside Europe, the Inter-American Court of Human Rights (IACHR) applied in a landmark ruling treaty-based rights to annul a ban on carrying out IVF in Costa Rica. ${ }^{19}$ In Murillo and Others $v$ Costa Rica, the Court interpreted the scope of, among others, private and family life under the American Convention on Human Rights. Referring to other international human rights courts, the IACHR concluded that private life is a broad concept, "encompassing aspects of physical and social identity, the right to personal autonomy (...)", including "the decision of whether or not to become a mother of father in the genetic or biological sense" (para 143). ${ }^{20}$ Moreover, the right to private life is closely related to reproductive autonomy and access to reproductive services" (para 146), as confirmed by Article 16(e) of the Convention for the Elimination of All Forms of Discrimination against Women (CEDAW). ${ }^{21}$ Therefore, the scope of private life and reproductive autonomy, ... give rise to the right to have access to the best health care services in assisted reproductive techniques (para 150). A ban on IVF can be considered as an interference with a woman's private life, as it hinders her right to control her fertility. Consequently, violating a woman's reproductive autonomy, and thus the right to private life. In addition, such a ban cannot be considered as justified as it involves an arbitrary (i.e. discriminatory to infertile women) and excessive interference in private ... life that makes this interference disproportionate (para 316). ${ }^{22}$ As a result, the Court ${ }^{18}$ E.g., Mennesson v France and Labassee v France Appl. nos. 65192/11 and 65941/11 (ECtHR 26 September 2014) concerning the refusal to grant legal recognition to intended parents-child relationship that has been legally established in the US by gestational surrogacy; D and Others $\mathrm{v}$ Belgium concerning the initial refusal to authorise the arrival on its territory of a child who was born in the Ukraine from a surrogate pregnancy (Arts 3 and 8); Paradiso and Campanelli v Italy Appl. no. 25358/12 (ECtHR 25 January 2017): the placement of a nine-month-old baby in social service care who was born in Russia following a gestational surrogacy contract (Art. 8); Foulon v France and Bouvet v France Appl. nos. 9063/14 and 10410/14 (ECtHR, 21 October 2016) and Laborie and Others v France Appl. no. 44024/13, (ECtHR 17 January 2017).

${ }^{19}$ Artavia Murillo and others v Costa Rica Inter-Am. Ct.H.R. no. 257, Judgement of 28 November 2012, http://corteidh.or.cr.

${ }^{20}$ Here the Court made reference to the comparative European jurisprudence, referring to Evans v UK, Dickson v UK, and S.H. and others v Austria.

${ }^{21}$ According to which women enjoy the right "to decide freely and responsibly on the number of and spacing of their children and to have access to the information, education and means that enable them to exercise these rights", Art. 16(e) CEDAW.

${ }^{22}$ Not mentioned here but also interesting is the Court's interpretation of the Convention's right to life (Art. 4(1)) with respect to the prohibition on IVF. It raises the dispute when human life begins, and thus when the embryo requires protection within the scope of Convention. ... According to the Court, protection from the moment of conception should be understood as, the moment at which implantation in the uterus occurs, instead of from the moment of fertilization of the gametes. This means that prior to implantation Article 4 of the Convention is not applicable (para 264). ordered Costa Rica to legalise IVF and to take necessary measures for safeguarding equal access to IVF services while respecting the principles underlying reproductive rights, such as non-discrimination, information and education, high quality care, etc. (para 381). As such, the Court ruling echoes the core elements of reproductive rights as defined in international human rights treaties (e.g., Article 12 ICESCR, and Article 16 CEDAW) and treaty-related documents (e.g., the General Comment on Health and CEDAW Recommendation no. 24).

\section{Conclusion}

What becomes clear is the following. So far, both the European and the Inter-American Human Rights Court have accepted the idea that the private life concept encompasses access to reproductive care. And thus imposes States to adopt positive measures securing the right to procreate by means of IVF technology. In case of a contested measure (e.g., ban on IVF and/or PGD, the analytical approach is similar: i) whether an interference is in accordance with the law and pursued a legitimate aim (e.g. protecting public morals or public health), and ii) to determine whether the measures taken were "necessary in a democratic society", reviewing whether the reasons where relevant and sufficient for the purpose (not arbitrary or unreasonable). ${ }^{23}$ But overall, the outcomes of such an analysis leave individual States a wide margin of appreciation justifying restrictive measures on ARTs. A new dimension to this approach will be added in case of the denial of "medically assisted procreation" to same-sex couples, whether such a refusal results in discrimination based on sexual orientation (Art. 14 in conjunction of Art. 8 of the Convention). ${ }^{24}$ Will the Court accept a same-sex couple's controversial right to assisted procreation under the Convention? Most likely, the Court will reiterate that 'for the purpose of Article 14, a difference in treatment is discriminatory if it has no objective and reasonable justification, which means that it does not pursue a "legitimate aim" or that there is no "reasonable proportionality between the means employed and the aim sought to be realised" ${ }^{25}$ And related to sexual orientation, "there is a need for particularly convincing and weighty reasons to justify a difference in treatment regarding rights falling within Article 8'. In the Court's option, refusing same-sex couples assisted precreation based solely on sexual orientation will be considered as discriminatory and need very weighty reasons for denial when such services are available for heterosexual couples.

\section{Acknowledgement}

None.

\section{Conflict of interest}

None.

\footnotetext{
${ }^{23}$ Knecht v Romania Appl. no. 10048/10, ECtHR 2 October 2012, paras 56-60. ${ }^{24}$ Complaint lodged in 7 May 2015 by Charron and Merle-Montet v France Appl. no. 22612/15 (pending) in conjunction with Art. 8. ${ }^{25}$ E.B. v France Appl. no. 43546/02 (ECtHR, 22 January 2008) para 91.
} 